\title{
Strengthening of a steel girder with web openings
}

\author{
Andrzej Wojnar ${ }^{1, *}$, and Edyta Bernatowska ${ }^{1}$ \\ ${ }^{1}$ Department Building Structures, Rzeszow University of Technology, Poland
}

\begin{abstract}
The paper presents results of investigation carried out on structure of the cultural center building in Dębica in Poland. Technical condition of mentioned building after 40 years of exploitation did not allow for its further use. In order to check the reliability of the structure, the authorities of the city commissioned an expertise. This study included basic structure measurements, loads statement and static analysis as well as check of limit states. As a result of the conducted analyses, it was found that the roof structure made of steel girder with web openings did not comply with resistant conditions. The paper presents brief description of building structure, numerical analyses and proposals of strengthening the roof girder.
\end{abstract}

\section{Introduction}

Using of beam with web openings is very common in building structures. By reason of openings it is possible to accommodate services such as air conditioning and reduce depth of area for suspended installation ducts. Beams also gain higher bending resistance without increasing its self-weight. The behaviour of these beams is generally considered similar to a Vierendeel beam. Many analytical, numerical and experimental studies have been conducted to develop different calculation approaches for beams with hexagonal, circular [1-3], elongated or oval openings [4-6] as well as novel opening shapes [7, 8]. Due to the openings the most sensitive element to load change is web, especially the zones of high shear due to Vierendeel failure mechanism. It is one of the local failure mode linked with the local bending of the members around the openings due to the transfer of shear force between the opening boundaries [9]. Taking above into account, several special methods of strengthening are known and used. Most common solution is adding different types of stiffeners welded vertically or horizontally in one or two web-sides [10]. The other types of strengthening methods are using of fibre reinforced polymer composite plates adhesively bonded to the steel surface $[11,12]$. This paper focuses on numerical analysis of steel frame with roof girder made of beam with hexagonal web openings and presents proposals of its strengthening by change of static schema.

\footnotetext{
*Corresponding author: awojnar@prz.edu.p1
} 


\section{The subject of analysis}

The building of the cultural center in Dębica was built in the 1970s. Originally the object was used as a boxing hall, but after 40 years of exploitation, its technical condition did not allow for further use. The city's authorities decided to renovate building and change its function. The new project included: the creation of auditorium for nearly 600 seats and an amphitheatre scene, new wardrobes, sound system and lighting. The whole object was supposed to be adapted to the needs of disabled people. During renovation works damages of the roof girders were detected, Fig. 1. For the above reasons the Department of Building Structures of Rzeszow University of Technology was asked to carry out independent examination of the roof structure and prepare expertise with proposal of strengthening.

a)

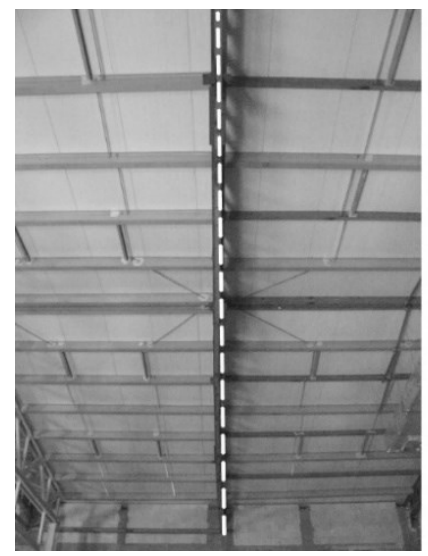

b)

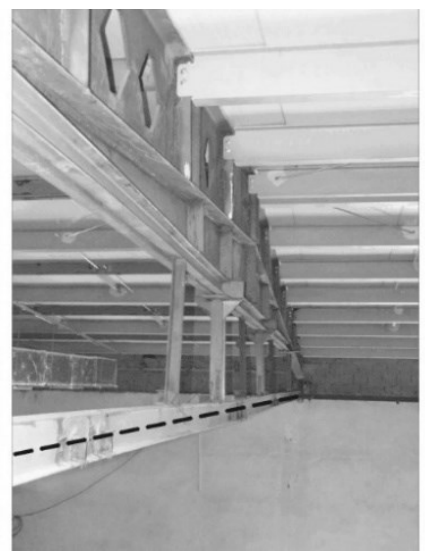

c)

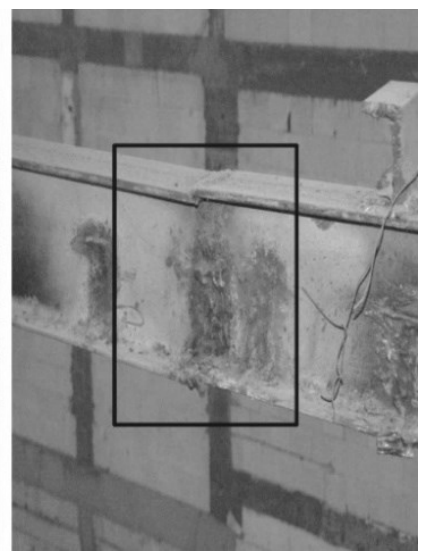

Fig. 1. (a) out-of-plane deformation of roof girder; (b) in-plane deformation of roof girder (c) example of a welded connection in the structure.

\section{Description of the existing structure}

The cultural centre building includes two aisles. The dimensions of the building in the axes are equal to $33.0 \mathrm{~m} \times 83.20 \mathrm{~m}$, Fig. 2. The span of aisles are $21 \mathrm{~m}$ and $12 \mathrm{~m}$. The main aisle height measured from the floor to the support of the girders is $7.95 \mathrm{~m}$, Fig. 3. The structure of the building has been designed as a steel frame with the distance between frames equal to $6.4 \mathrm{~m}$. The frame in wider part of building consists of steel girder made of IN 450 profile. The girder is simply supported on steel round columns (circular hollow cross-section) $\varnothing 406$ with thickness $13 \mathrm{~mm}$. The height of the roof girder with hexagonal openings reaches 600 $\mathrm{mm}$, whereas the hexagonal openings are $0.30 \mathrm{~m}$ height and are in $0.43 \mathrm{~m}$ longitudinal spacing. Girders are strengthened with gusset plate with a 10mm thickness, welded to IN450 bottom flanges and two channels $\mathrm{C} 100$ welded with webs to the gusset plate. Every third opening in the girder web is filled with a $10 \mathrm{~mm}$ thickness plate (in the place where the girder meets the purlins). In the level of approx. $650 \mathrm{~mm}$ below the axis of the roof girder there is a tie-beam made of IPE140. Tie-beam is connected with columns of main frame using pinned joint and witch bottom flange of girder using four tie-bars made of IPE140.

Roof girders in second aisle have been made of IPE 400 profile also simply supported on steel columns (hollow cross-section Ø355.6).

Purlins have been designed as simply supported beams. Two different types of profiles were used: IPE 140 - which are the originally designed beams and IPE 220 which are new elements, designed and installed during the ongoing renovation. The purlins are arranged 
alternately at a distance $1.3 \mathrm{~m}$. In addition to self-weight of the roof and climatic loads (wind and snow), purlins also carry load from suspended ventilation ducts, platforms and elements of sound system and lighting.

According to archival design documentation, all steel elements of the structure were made of steel with yield strength $\mathrm{f}_{\mathrm{y}}=235 \mathrm{~N} / \mathrm{mm}^{2}$.

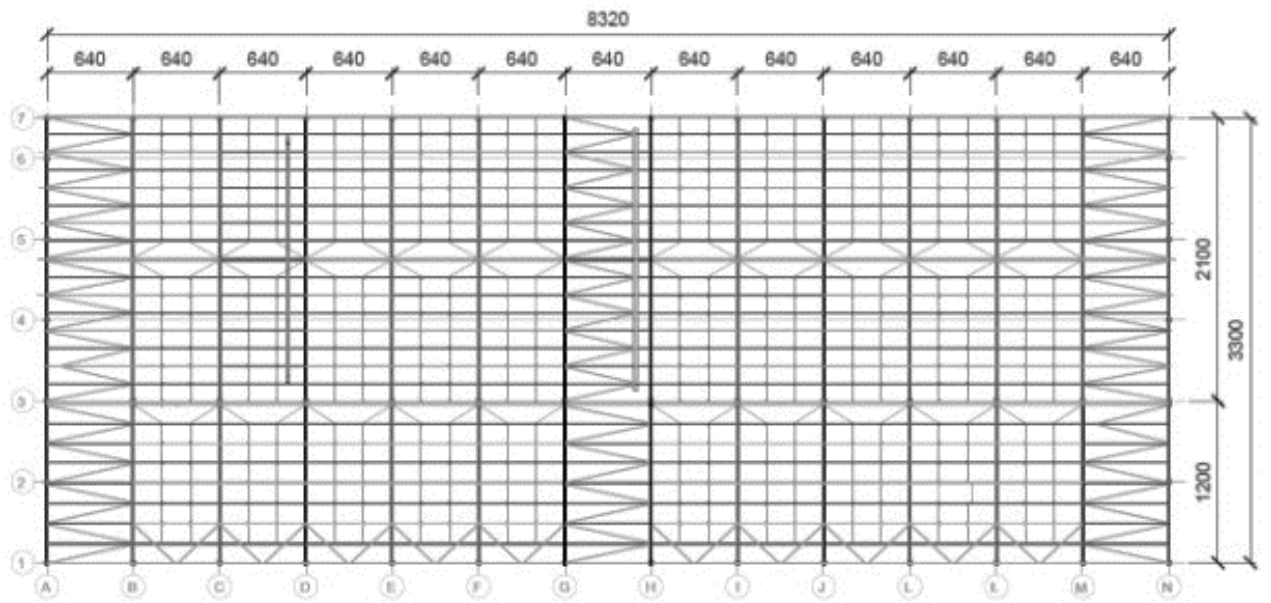

Fig. 2. Top view of the roof structure (dimensions in $\mathrm{mm}$ ).

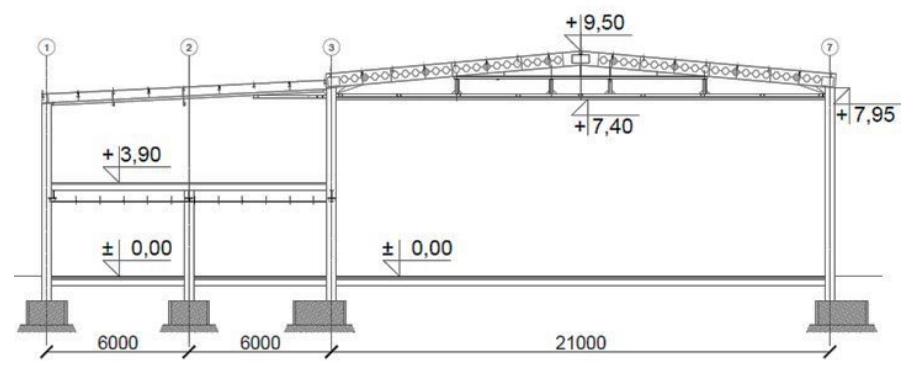

Fig. 3. Cross section of the building (dimensions in $\mathrm{mm}$ ).

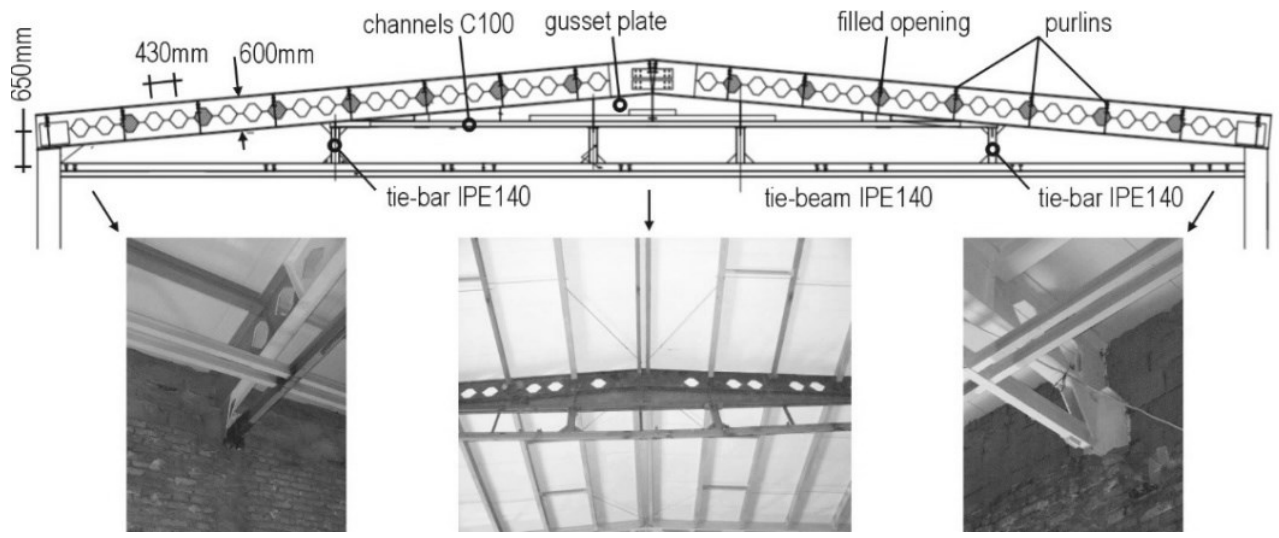

Fig. 4. View of steel girder. 


\section{The numerical model of existing structure}

The view of two-dimensional numerical model of analysed main frame of the structure was presented on Fig. 5. The model was made using the Autodesk Robot Structural Analysis Professional (ARSAP) software [13].

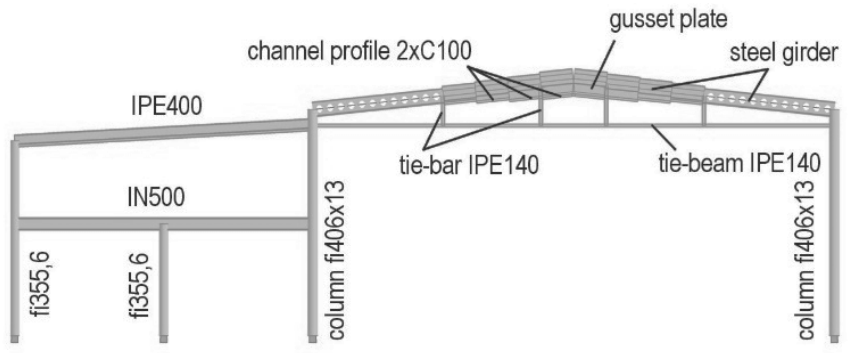

Fig. 5. View of the structure model.

Model of the structure was made using bar elements. Types of cross-sections of model's elements (columns, roof girder, tie-beam, tie-bars, roof beam) were described in section 3. Connections between all columns and foundations were modelled as rigid joints. Connections between roof girders, beams (IPE400, IN500) and columns were modelled as pinned joints.

The structure was loaded by following types of loads: dead load, live loads, climatic loads [14], self-weight of roofing, purlins, working platforms, sound system, lighting and installations. Live load of suspended to working platforms and self-weight of installations were obtained based on information from the investor of the building and applied to roof girder (beam with openings). Snow load was calculated according to Polish standard and applied as a nodal forces to upper flange of roof girder, Fig. 6.

The calculations were carried out in accordance with Polish standards because these standards allow to check the stability of beams with web openings and taking into account the increased value of snow load on the ground. This value was obligatory to use after the catastrophe in Katowice in 2006.

At first, during designing, existing structure was calculated taking into account snow load on ground obtained according to Polish codes which were obligatory in 1970 [15]. Because the value of snow load on ground calculated according to those Polish standards was less than calculated in accordance with the standard updated in 2006, values of internal forces were smaller. Because of it, it was necessary to recalculate internal forces in the structure and check stability of structure and elements of the structure. This fact was also one of the reason of making this expertise. 


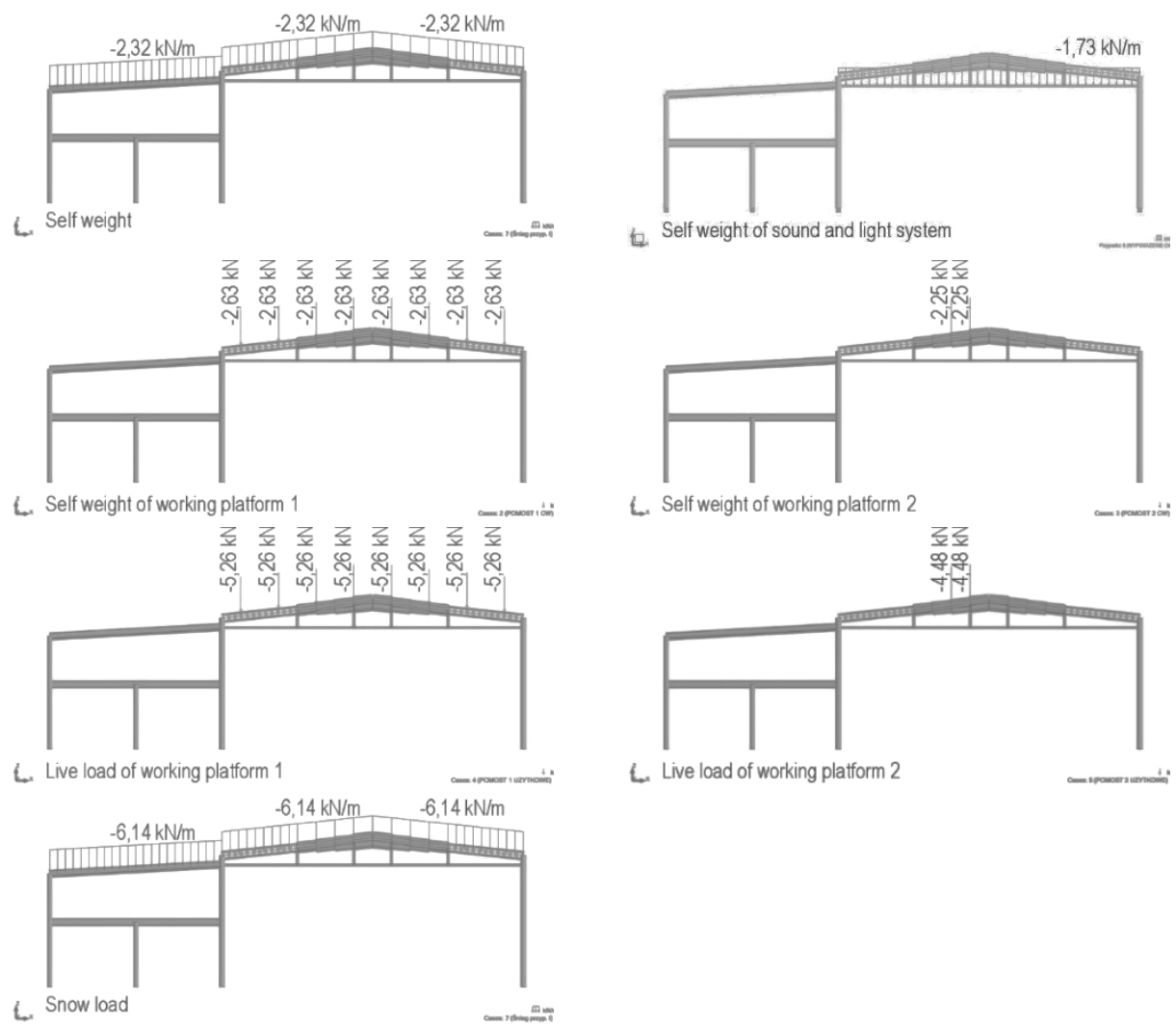

Fig. 6. View of applied loads in created model.

\section{Checking stability of existing structure}

To check stability of the structure and its elements the numerical simulations were conducted. Internal forces were calculated using first order analysis. Stability of elements were checked taking into account bending moment and axial compression or tension. The reduction factor for the relevant buckling mode and the value of lateral torsional buckling factor were calculated taking into consideration the buckling length of elements and shape of bending moments diagrams.

In calculations measured geometrical imperfections of the tie-beam were taken into account. This imperfection were measured by the geodesist team in the horizontal and vertical direction.

The capacity of following elements were calculated: the middle and side part of roof girder, tie-beam and tie-bars, Fig. 7.

The capacity of roof girder with hexagonal openings as a value of equivalent stress in compression chord and web was calculated according to procedure based on polish standards and described in [16]. Required (in this procedure) value of the coefficient of lateral torsional buckling was obtained using Autodesk Structural Robot software.

The capacity of tie-beam and tie-bars were checked in Autodesk Structural Robot software.

During calculations the value of yield strength $f_{y}=235 \mathrm{~N} / \mathrm{mm}^{2}$ was taking into account while checking the resistance of cross-section and stability of elements. Results of calculations were presented on Table 1. It can be seen that the part of girder with hexagonal 
openings in the web and tie-beams did not comply with resistant conditions. Hence, a few proposals of girder strengthening were analysed.

Stability of elements of main structure was checked taking into account following conditions:

1. Roof girder - bending and axial compression

- lateral torsional buckling length was taken as: a distance between corner or ridge node of the frame and zero point of diagram of bending moment for lower flange of roof girder, a distance between corner or ridge node of the frame and zero point of diagram of bending moment or distance between purlins for upper flange of roof girder.

2. Tie-beams in tension with bending.

3. Tie-bar in tension.

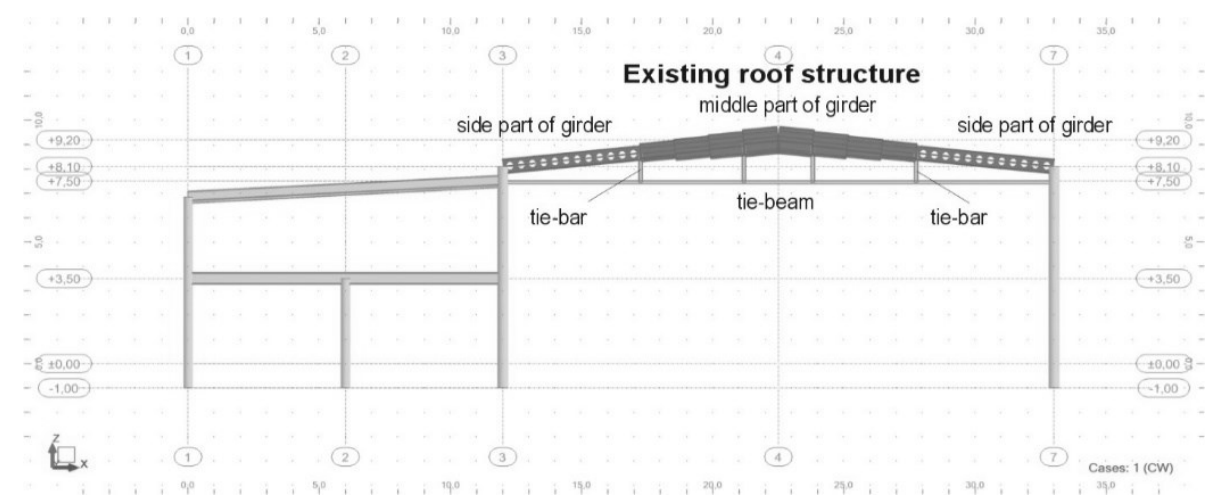

Fig. 7. View of the main frame of existing structure.

Table 1. Resistance ratio of roof girder elements.

\begin{tabular}{|c|c|c|c|}
\hline Member & Section & Ratio & $\begin{array}{c}\text { Stress } \\
\mathrm{N} / \mathrm{mm}^{2}\end{array}$ \\
\hline $\begin{array}{c}\text { Equivalent stress in compression } \\
\text { flange - point A - Fig. 8 }\end{array}$ & IN 450/600 & - & 249.8 \\
\hline $\begin{array}{c}\text { Equivalent stress in web - point A } \\
\text { - Fig. 8 }\end{array}$ & IN 450/600 & - & 48.0 \\
\hline $\begin{array}{c}\text { Equivalent stress in gross cross- } \\
\text { section - point B - Fig. 8 }\end{array}$ & IN 450/600 & - & 235.5 \\
\hline Tie-beam & IPE 140 & 1.10 & - \\
\hline Tie-bars & IPE 140 & 0.03 & - \\
\hline
\end{tabular}
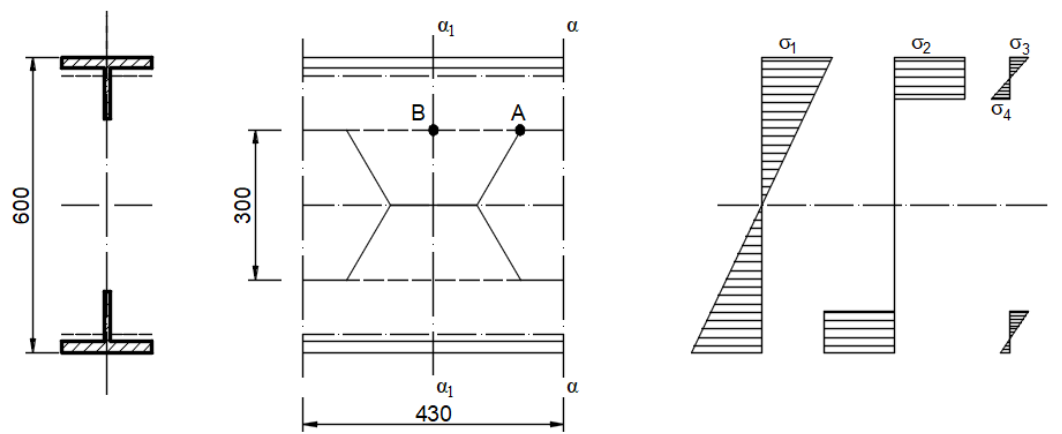

Fig. 8. Points in which stress values were calculated 


\section{Conclusions}

Based on results of calculations the following major conclusion can be formulated:

- the carrying capacity of the roof girder (especially roof beam with hexagonal web openings and tie-beams) is not enough,

- it is necessary to strengthening the structure to meet the requirements of limit states: Ultimate Limit State and Serviceability Limit State, Strengthening of the structure can be made by following methods [17-22]:

1. Replacement of old elements with new ones, made from steel about value of yield strength $\mathrm{f}_{\mathrm{y}}$ greater than $235 \mathrm{~N} / \mathrm{mm}^{2}$ (for example steel grade $\mathrm{S} 355$ with $\mathrm{f}_{\mathrm{y}}=355 \mathrm{~N} / \mathrm{mm}^{2}$ ).

2. Adding new elements to existing structure to increase geometrical characteristics of cross-sections (area of cross-sections, moment of inertia).

3. Reduction elements span, execution of additional supports of structure.

4. Changing the type of the structure - changing static schema of the structure.

Because of destination of the building (the larger frame was structure of the amphitheatre scene) the investor decision was, that solutions number 1, 2 and 3 are not recommended or impossible to apply. Finally it was decided to perform the strengthening of the structure by changing static schema of the structure. A new type of structure was presented on Fig. 8. The following types elements were proposed and added to the structure:

- additional brace members: post and diagonals - made of profile RHS 120x60x8,

- additional brace member as a new part of tie-beam - made of plate 20x160 mm,

- single plate $14 \times 140 \mathrm{~mm}$ welded to existing IPE bottom flange along the entire length,

- double plates $10 \times 150 \mathrm{~mm}$ welded to IPE flanges to improve lateral torsional buckling resistance of the I-section (caused by geometrical imperfections of tie-beam).

Due to the need to carry out ventilation ducts, it was not possible to design additional diagonals in the middle part of roof structure.

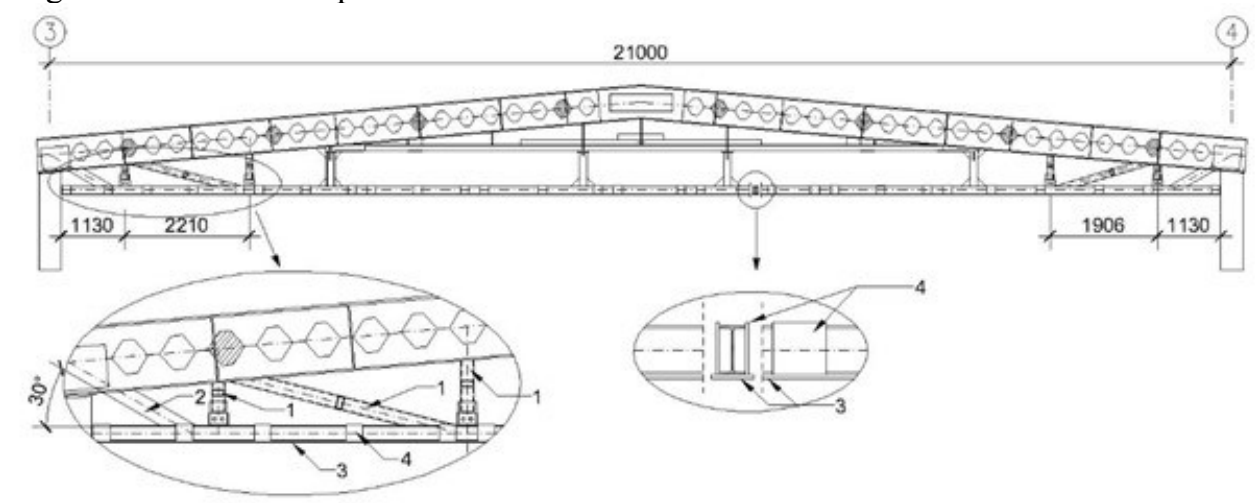

Fig. 8. Proposal of the roof girder strengthening: 1-additional RHS 120x60x8 brace members, 2- single plate $20 \times 160 \mathrm{~mm}, 3$ - single plate $14 \times 140 \mathrm{~mm}, 4$ - double plates $10 \times 150 \mathrm{~mm}$.

\section{The numerical model of strengthening structure}

The numerical model of strengthening steel structure (Fig. 9) was made using ARSAP software. Additional elements (posts, diagonals, steel plates) described in section 5 were introduced to existing model. The structure was loaded in the same way, like existing structure. To calculate internal forces the first order analysis was used. Resistance of crosssections and stability of the structure and elements of the structure were determined by the same way like in case existing structure. Results of calculations were presented on Table 2. 


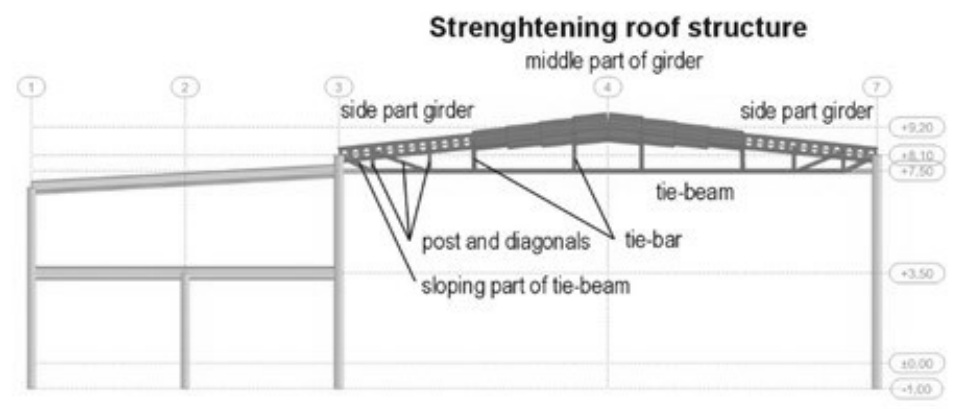

Fig. 9. View of the main frame of strengthening structure.

Table 2. Resistance ratio of roof girder elements after strengthening

\begin{tabular}{|c|c|c|c|}
\hline Member & Section & Ratio & $\begin{array}{c}\text { Stress } \\
\mathrm{N} / \mathrm{mm}^{2}\end{array}$ \\
\hline $\begin{array}{c}\text { Equivalent stress in compression } \\
\text { flange }\end{array}$ & IN 450/600 & - & 86.5 \\
\hline $\begin{array}{c}\text { Equivalent stress in web } \\
\text { Equivalent stress in gross cross- } \\
\text { section }\end{array}$ & IN 450/600 & - & 40.5 \\
\hline Tie-beam & IPE 140 & 1.10 & 46.4 \\
\hline Tie-bars & IPE 140 & 0.03 & - \\
\hline Sloping part of tie-beam & plate 20x160 & 0.68 & \\
\hline Posts and diagonals & RHS 120x60x8 & 0.37 & \\
\hline
\end{tabular}

\section{Summary}

Taking into account results of both calculations, the following conclusion can be made:

- strengthening structure, designed according to Polish codes, comply with resistant conditions,

- changing static-schema of the structure, adding posts and diagonals and strengthening of tie-beam of roof structure, was an effective method of strengthening of the structure. In this case this method was easy to use and cheaper than another ones,

- because of using this method values of internal forces, normal stress and ratio of structure elements were reduced.

The view of the structure after strengthening was presented on Fig. 10. 


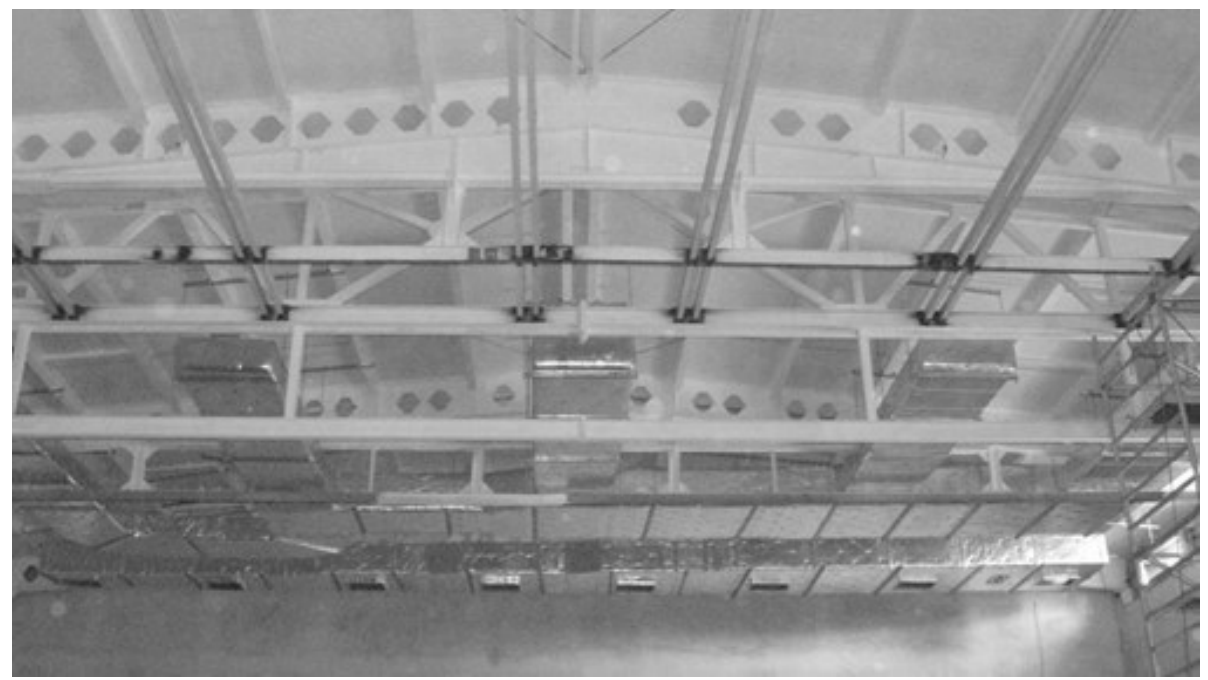

Fig. 10. Picture of the structure after strengthening.

\section{References}

1. D. Darwin, Design of steel and composite beamswithweb openings, Design Guide 2, (AISC, 2003)

2. F. Erdal, P.S. Mehmet, J. Constr. Steel Res., 80, pp. 355-368 (2013)

3. R.M. Lawson, Steel Constr, Instit, 68 (1984)

4. P. Pattamad, T. Thaksin, L. Suchart, J. Constr. Steel Res., 112, pp. 10-21 (2015)

5. K.D. Tsavdaridis, C. D'Mello, J. Constr. Steel Res. 76, pp. 39-53 (2015)

6. S. Tudjono, Sunarto, A.L. Han, IOP Conf. Series: Mater. Sci. Eng. 271, 012104 (2017)

7. K.D. Tsavdaridis, C. D'Mello, J. Struct. Eng., 138(10), pp. 1214-1230 (2012)

8. K.D. Tsavdaridis, J.J. Kingman, V.V. Toropov, Comput. Struct., 158, pp. 108-123 (2015)

9. K.F. Chung, T.C.H. Liu, A.C.H. Ko, J. Constr. Steel Res., 57(5), pp. 467-490 (2001)

10. T. Al-Dafafea, S. Durif , A. Bouchar, E. Fournely, J. Constr. Steel Res., 154, pp. 149-160 (2019)

11. M.J. Altaee, L. S. Cunninghama, M. Gillie, J. Constr. Steel Res., 138, pp. 750-760, 2017)

12. M. Altaee, L. S. Cunninghamb, M. Gillie, J. Constr. Steel Res., 155, pp. 395-408 (2019)

13. Autodesk Robot Structural Analysis Professional (2018)

14. PN-80/B-02010 Obciążenia w obliczeniach statycznych -- Obciążenie śniegiem [in Polish]

15. PN-B-03200 Konstrukcje stalowe -- Obliczenia statyczne i projektowanie [in Polish]

16. M. Łubiński, A. Filipowicz, W. Żółtowski, Metal structures 1 (Arkady, Warszawa ,2003)

17. M. Kazek, B. Kowolik, Strengthening of steel structure across the change of static schema of the structure (Proceedings of the $31^{\text {st }}$ Conference Warsztaty Pracy Projektanta Konstrukcji, Szczyrk, 2016) [in Polish] 
18. J. Augustyn, J. Skotny, Temporary guidelines strengthening of elements of steel structures by weldings under the load. (Stowarzyszenie Projektantów Konstrukcji Budowlanych, Warszawa, 1991) [in Polish]

19. J. Laguna, The repair and the strengthening of steel structures through the change of cross-sections, Proceedings of the $23^{\text {rd }}$ Conference Warsztaty Pracy Projektanta Konstrukcji, Szczyrk, 2008) [in Polish]

20. J. Ziółko, The maintenance and the modernization of steel structures (Arkady, Warszawa 1991) [in Polish]

21. E. Masłowski, D. Spiżewska, Strengthening of buildings and structures (Arkady, Warszawa, 2000) [in Polish]

22. C. Linczowski, Repairs and modernizations of buildings (The Publishing House of the Kielce Technical University, Kielce, 1997) [in Polish] 